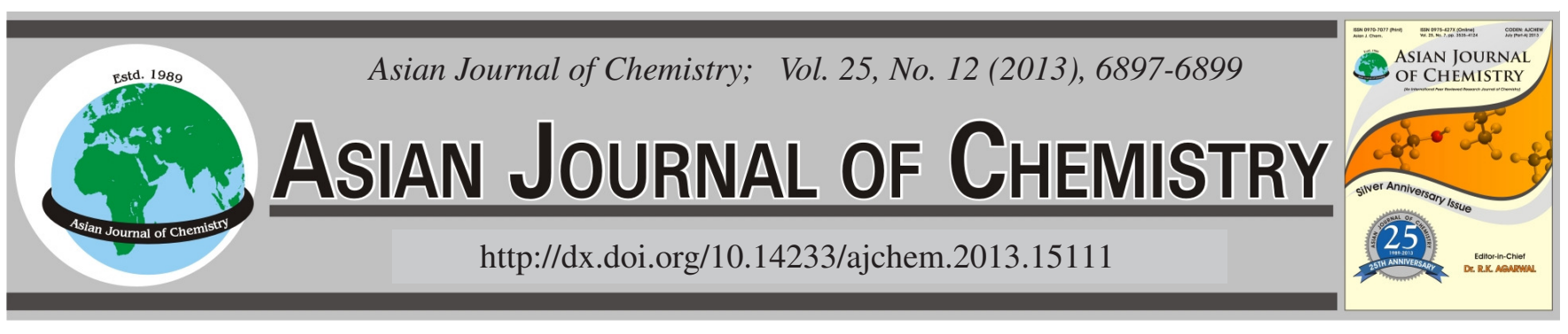

\title{
Effect of Immobilization Towards Thermal Stability of $\alpha$-Amylase Isolated from Locale Bacteria Isolate Bacillus subtilis ITBCCB148 with Calcium Alginate
}

\author{
YAndri ${ }^{*}$, Putri Amalia, Tati Suhartati and Sutopo Hadi*
}

Department of Chemistry, Faculty of Mathematics and Natural Sciences, University of Lampung, Bandar Lampung 35145, Indonesia

*Corresponding authors: E-mail: yandrias@unila.ac.id; sutopohadi@unila.ac.id

(Received: 9 January 2013;

Accepted: 5 June 2013)

AJC-13597

\begin{abstract}
The research aims to increase the thermal stability of enzyme of $\alpha$-amylase obtained from local bacteria Bacillus subtilis (ITBCCB148) using immobilization process with entrapment method using alginate as the immobile matrix. To achieve this aim, the purification of enzyme was performed on the following phases: fractionation with ammonium sulphate, dialysis and colomn chromatography with CMcellulose. The result showed that the native enzyme which has been purified has optimum temperature of $55^{\circ} \mathrm{C}$. The thermal stability test at $60{ }^{\circ} \mathrm{C}$ for $1 \mathrm{~h}$, the native enzyme has residual activity of $3 \%, \mathrm{t}_{1 / 2}=11 \mathrm{~min}, \mathrm{k}_{\mathrm{i}}=0.063 \mathrm{~min}^{-1}$ and $\Delta \mathrm{G}_{\mathrm{i}}=100.859 \mathrm{~kJ} \mathrm{~mol}^{-1}$; while for the immobilized enzyme the values obtained were residual activity of $68 \%, \mathrm{t}_{1 / 2}=115.5 \mathrm{~min}, \mathrm{k}_{\mathrm{i}}=0.006 \mathrm{~min}^{-1}$ and $\Delta \mathrm{G}_{\mathrm{i}}=107.369 \mathrm{~kJ} \mathrm{~mol}^{-1}$. The optimum temperature of immobilized enzyme was $60^{\circ} \mathrm{C}$. The thermal stability of the imobilized enzyme was 10.5 times compared to the native enzyme. On repeating use, the immobilized enzyme was able to be used 4 times.
\end{abstract}

Key Words: Immobilization, Calcium alginate, Thermal stability, $\alpha$-Amylase, B. subtilis, ITBCCB148.

\section{INTRODUCTION}

Commercially, enzyme is widely used in many industrial sectors that utilizes the biocatalytic activity of the eznyme which works specifically and efficiently ${ }^{1}$. Generally, enzyme has some weaknesses, besides the expensive cost of the enzyme but also the characteristic of the enzyme which only can be used once, work only at physiological condition and can't stand under extreme condition ${ }^{2}$. These problems may be solved by increasing the stability of the enzyme by the chemical modification, direct mutagenesis and immobilization ${ }^{3}$.

The enzyme immobilization has some advantages compared to the other methods such as (1) The immobilization of enzyme can protect the opening the enzyme protein foldings which cause the decrease of the enzyme activity, which increase the enzyme structure stability as a result the enzyme can be used repeatedly ${ }^{4}$; (2) It has wide active side so the contact of substrate and enzyme is more effective $e^{5}$; it can easily be separated from mixture of medium and cell, so it can be used for the next production continously ${ }^{6,7}$.

The lysine residue on the surface of the enzyme is one of the enzyme instability as the enzyme can interact with water molecule surround it. By immobilization technique, it is expected that the lysine structure is protected by gel of supporting material formed so the enzyme is more stable. The supporting material oftenly used for enzyme immobilization are $\kappa$ caragenan, polyacrylamide, synthetic resin and calcium alginate $^{8}$. In our previous research, we have performed immobilization process on $\alpha$-amylase obtained from locale bacteria isolate Bacillus subtilis ITBCCB148 using supporting matrix of DEAE-Celullose and CM-Celullose ${ }^{9,10}$. The results showed that the immobilized enzyme were increased its thermal stability up to 1.5 to 3.67 times compared to the native enzyme.

In this research the supporting material used for immobilization was calcium alginate $\left(\mathrm{C}_{6} \mathrm{H}_{8} \mathrm{O}_{6}\right)_{2} \mathrm{Ca}$. The choice of this supporting material is that calcium metal is not toxic, the stability of mechanism is high, the high porosity and simple procedure $^{11}$. The immobilization is performed to increase the enzyme stability and to reduce the use of the enzyme in once process to many times by low cost.

\section{EXPERIMENTAL}

All chemicals used were the materials with high grade (pro analysis) purity. Locale bacteria isolate B. subtilis ITBCCB148 was obtained from Microbiology and Fermentation Technology Laboratory, Chemical Engineering Department, Bandung Institute of Technology, Bandung, Indonesia.

The following research phases were done i.e., the production, isolation, purification and characterization of the native enzyme were based on our previous report ${ }^{9}$.

Activity test of $\alpha$-amylase and determination of protein content: Activity of $\alpha$-amylase was determined based on the 
iodine method ${ }^{12}$ and using dinitrosalicylic acid reagent ${ }^{13}$. The protein content was determined based on the method by Lowry et al. ${ }^{14}$.

Immobilization of purified enzyme with calcium alginate $^{8}: 2 \mathrm{~mL}$ of $\alpha$-amylase was transferred to $6 \mathrm{~mL}$ of $4 \%$ sodium alginate solution then completely mixed. The mixture was then put in the syringe and added drop wise to beaker glass containing $100 \mathrm{~mL}$ of $0.1 \mathrm{M} \mathrm{CaCl}_{2}$ with shaking until the calcium alginate gel containing enzyme was formed and then it was kept in freezer for 20 min. Finally it was washed with aquadest 3 time, then dried at room temperature.

Characterization of enzyme before and after immobilization: The characterization of enzyme before and after modification included: determination of thermal stability, thermodinamic data and repeat use of immobilized enzyme.

Stability test of enzyme before and after immobilization $^{15}$ : The test of stability of enzyme was performed by measuring the residual activity of the enzyme after being incubated for $0,10,20,30,40,50$, and $60 \mathrm{~min}$ at optimum temperature, where the initial activity of enzyme without heating was given a value of $100 \%$.

Repeated use of the enzyme: The immobilzed enzyme which has been used (which has been reacted with substrate) was reacted again with substrat using Fuwa's method ${ }^{12}$. The process was repeated for six times.

Determination of half-life $\left(t_{1} / 2\right), k_{i}$ and $\Delta G_{i}$ : Determination of $\mathrm{k}_{\mathrm{i}}$ value (thermal inactivation rate constant) and the denaturation energy change $\left(\Delta \mathrm{G}_{\mathrm{i}}\right)$ of the native enzyme and the immobilized enzyme was done using known procedures ${ }^{15}$.

\section{RESULTS AND DISCUSSION}

Determination of optimum temperature of native and immobilized enzyme: Fig. 1 shows the optimum temperature of the native enzyme is $55^{\circ} \mathrm{C}$, while the immobilized enzyme is $60^{\circ} \mathrm{C}$. The immobilized enzyme requires higher temperature to convert the substrate to the product. This is due to the steric hindrance where the enzyme was entraped in the matrix of calcium alginate. Fig. 1 also shows that the immobilized enzyme is more stable at higher temperature up to $80^{\circ} \mathrm{C}$.

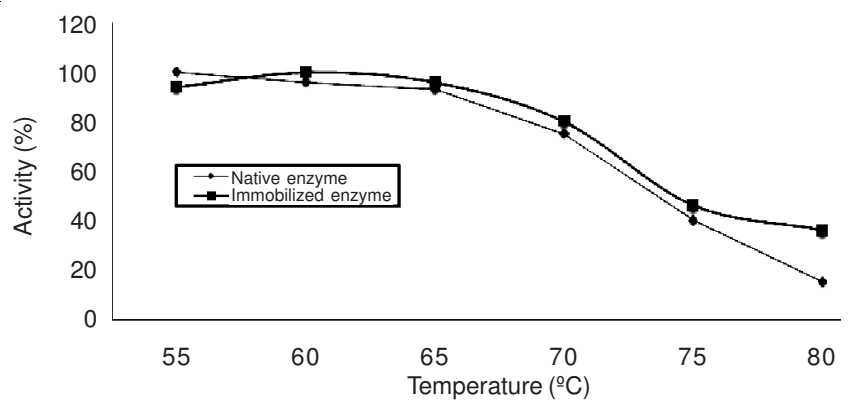

Fig. 1. Optimum temperature of the native and immobilized enzyme

Effect of immobilization toward thermal stability of the immobilized enzyme: Fig. 2 shows the relationship of residual activity against the time of native and immobilized enzyme which was kept at $60{ }^{\circ} \mathrm{C}$ for $1 \mathrm{~h}$. The immobilized enzyme has residual activity much higher than that of the native enzyme. \% residual activity of the native enzyme after being kept for $1 \mathrm{~h}$ was only $3 \%$ compared to the immobilized enzyme with residual activity of $68 \%$. This result was because the immobilized enzyme which was in the immobile matrix was able to protect itself from the physical effect which can cause the protein denaturation, as a result the immobilized enzyme was by far much stable compared to the native enzyme.

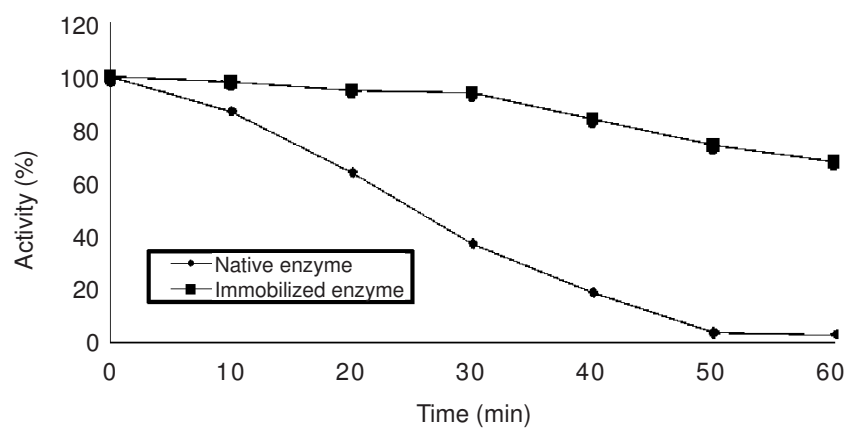

Fig. 2. Relationship of thermal stability of native and immobilized enzymes at $60^{\circ} \mathrm{C} v s$. time

The constant of thermal inactivation $\left(\mathrm{k}_{\mathrm{i}}\right)$, half-life $\left(\mathrm{t}_{1 / 2}\right)$ and the change of energy due to denaturation $\left(\Delta \mathrm{G}_{\mathrm{i}}\right)$ of native and immobilized enzymes. The constant of thermal inactivation $\left(\mathrm{k}_{\mathrm{i}}\right)$, half-life $\left(\mathrm{t}_{1 / 2}\right)$ and the change of energy due to denaturation $\left(\Delta \mathrm{G}_{\mathrm{i}}\right)$ of native and immobilized enzymes are shown in Table-1.

TABLE-1

CONSTANT OF THERMAL INACTIVATION $\left(\mathrm{k}_{\mathrm{i}}\right)$, HALF-LIFE $\left(\mathrm{t}_{1 / 1}\right)$

AND THE CHANGE OF ENERGY DUE TO DENATURATION $\left(\Delta \mathrm{G}_{\mathrm{i}}\right)$ OF NATIVE AND IMMOBILIZED ENZYMES

\begin{tabular}{lccc}
\hline Enzyme & $\mathrm{k}_{\mathrm{i}}\left(\mathrm{min}^{-1}\right)$ & $\mathrm{t}_{1 / 2}(\min )$ & $\Delta \mathrm{G}_{\mathrm{i}}(\mathrm{kJ} / \mathrm{mol})$ \\
\hline Native & 0.063 & 11 & 100.859 \\
Immobilized & 0.006 & 115.5 & 107.369 \\
\hline
\end{tabular}

Half-life $\left(t_{1 / 2}\right)$ and constant of thermal inactivation $\left(k_{i}\right)$ : It can be seen from Table- 1 that the half-life of the immobilized enzyme has increased 10.5 times compared to the native enzyme where the half-life of the native enzyme was $11 \mathrm{~min}$, while the immobilized enzyme was $115.5 \mathrm{~min}$. According to $\mathrm{Stahl}^{16}$, the half-life of enzyme will increase the stability of the enzyme. The result indicated that the immobilized enzyme has stability much better than the native enzyme. The decrease of $\mathrm{k}_{\mathrm{i}}$ value from 0.063 to 0.006 is equal to the increase of halflife. The decrease of $\mathrm{k}_{\mathrm{i}}$ value is due to the immobile enzyme was protected by the matrix so the enzyme was not flexible in water and the protein unfolding was also less as a result the stability of the immobilized enzyme was increased ${ }^{17}$.

Change of energy due to denaturation $\left(\Delta \mathbf{G}_{i}\right)$ : The change of energy due to denaturation $\left(\Delta \mathrm{G}_{\mathrm{i}}\right)$ shown in Table-1 indicated that the $\Delta \mathrm{G}_{\mathrm{i}}$ of immobilized enzyme was $107.369 \mathrm{~kJ}$ $\mathrm{mol}^{-1}$ and it was much higher than the native enzyme wich a vlue of $100.859 \mathrm{~kJ} \mathrm{~mol}^{-1}$. The high increase of $\Delta \mathrm{G}_{\mathrm{i}}$ value of immobilized enzyme means that it requires more energy to denaturate the immobilized enzyme. The more rigid of the enzyme, the stronger the bond in the enzyme, thus the enzyme conformation will not easily unfold, as a result the tertiary structure of the enzyme will be upheld ${ }^{15}$.

Repeated use of the immobilized enzyme: The use of immobilized enzyme in converting enzymatically the starch 
to glucose is shown in Fig. 3. Fig. 3 showed that the immobilized enzyme was able to be used repeatedly 4 times. On the $6^{\text {th }}$ repetition, it has residual activity of $12 \%$. Fig. 3 also suggests that the immobilized enzyme was effective up to the $4^{\text {th }}$ repeat. The decrease of enzyme activity on further repetition is merely due to the loss of enzyme physically because the washing process.

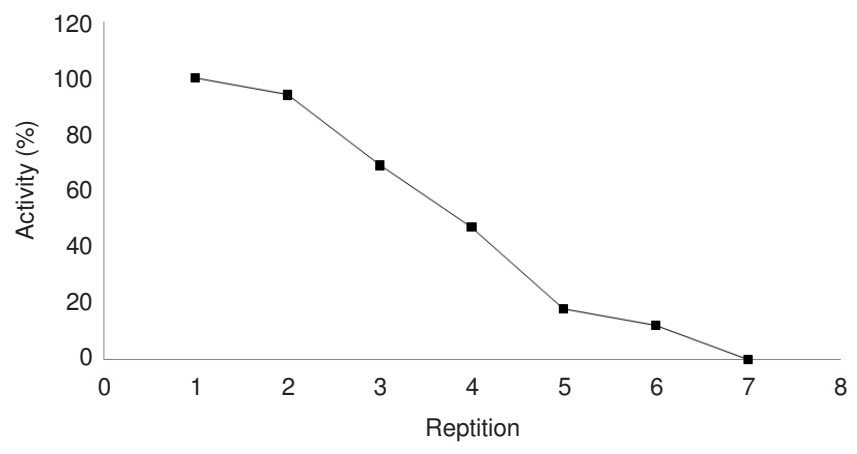

Fig. 3. Repeated use of immobilized enzyme

\section{Conclusion}

The immobilization with calcium alginate to $\alpha$-amylase obtained from local bacteria $B$. subtilis has effectively increased the thermal stability of the native enzyme. The immobilized enzyme was about 10.5 times thermally more stable than the native enzyme. This observation was also supported by the data of the decrease of ki value, the increase of half-life and $\Delta \mathrm{G}_{\mathrm{i}}$ values of the immobilized enzyme. On repeating used of the enzyme, it worked effectively 4 times.

\section{ACKNOWLEDGEMENTS}

The authors would like to thank to The Directorate of Research and Community Services, Directorate General of Higher Education. The Ministry of National Education of
Republic of Indonesia that provided funds for this project to be undertaken through competency based research scheme (Hibah Kompetensi) with contract number of 133/SP2H/PL/ Dit. Litabmas/III/2012, 7 March 2012.

\section{REFERENCES}

1. M.J. van der Maarel, B. van der Veen, J.C. Uitdeehag, H. Leemhuis and L. Dijkhvizen, J. Biotechnol., 94, 137 (2002).

2. I. Chibata, Immobilized Enymes; Kodansa Ltd.: Tokyo, pp. 9-54 (1978).

3. N.S. Melik-Nubarov, V.V. Mozheav, V.A. Siksnis and K. Martinek, Biotechnol. Lett., 9, 725 (1987).

4. L.W. Powel, in eds: T. Godfrey and S. West, Immobilized enzymes: Industrial Enzymology, MacMillan Press Ltd.: London, edn 2, pp. 265272 (1996)

5. K. Won, S. Kim, K. Kim, H.W. Park and S.J. Moon, Process Biochem., 40, 2149 (2005).

6. G. Payne, V. Bringi, C. Prince and M. Shuler, Plant Cell and Tissue Culture in Liquid Systems; Hanser Publishers: Munich-Vienna, pp. 177-223 (1992).

7. D.I.G. Wang, C.L. Cooney, A.L. Demain, P. Dunhill, A.E. Humprey and M.D. Lilly, Fermentation and Enzim technology; John Wiley \& Sons: New York, p. 374 (1979).

8. A. Riaz, S.H. Ul-Qader, A. Anwar and S. Iqbal, Aust. J. Basic Appl. Sci., 3, 2883 (2009).

9. Yandri, T. Suhartati and S. Hadi, Mater. Res. Sci. India, 7, 123 (2010).

10. Yandri, D. Susanti, T. Suhartati and S. Hadi, Mod. Appl. Sci., 6, 81 (2011).

11. C. Bucke, Methods Enzymol., 135, 175 (1987).

12. H. Fuwa, J. Biochem. (Tokyo), 41, 583 (1954).

13. M. Mandels, A. Raymond and R. Charles, Biotechnology and Bioengineering Symposium, John Wiley \& Sons Inc., vol. 6, p. 21 (1976).

14. O.H. Lowry, N.J. Rosebrough, A.L. Farr and R.J. Randall, J. Biol. Chem., 193 (1951).

15. D. Kazan, H. Ertan and A. Erarslan, Appl. Microbiol. Biotechnol., 48, 191 (1997).

16. S. Stahl, in ed: M.N. Gupta, Thermophilic microorganisms: The Biological Background for Thermophily and Thermoresistance of Enzymes: Thermostability of Enzymes; Springer Verlag: New Delhi, pp. 59-60 (1999).

17. Z. Yang, M. Domach, R. Auger, F.X. Yang and A.J. Russel, Enzyme Microb. Tech., 18, 82 (1996). 